\title{
NEW MODERN APRPROACHES TO MANAGING AGLOMERATION PROCESSES
}

\author{
Ondřej KULLA, Jan MINARČÍK, Ladislav KOČVARA \\ VSB - Technical University of Ostrava, Ostrava, Czech Republic, EU, \\ ondrej.kulla.st@vsb.cz, jan.minarcik@vsb.cz, ladislav.kocvara.st@vsb.cz
}

https://doi.org/10.37904/metal.2021.4281

\begin{abstract}
Agglomeration is an integral part of the metallurgical enterprise; its main task is production agglomerate used for the production of pig iron in blast furnaces. The production of the agglomerate consists of in the treatment of fine-grained ore material into a material with the required grain size, chemical composition and mechanical strength. The treatment of the material on the agglomeration is called sintering. To increase productivity and reduce emissions. The work describes the control of lime dosing directly into the mixing process before sintering of the agglomeration mixture.
\end{abstract}

Keywords: Sinterig plant, agglomeration, lime, silo

\section{INTRODUCTION}

The aim of the research is how important lime will be for the productivity of the agglomerate, as a secondary effect, reducing emissions. Lime has been shown to have a positive effect on the productivity of the agglomeration process and fuel savings. Lime as an intensifier of the agglomeration process ensures improved agglomeration and permeability of the agglomeration mixture. The addition of lime to the agglomeration mixture indicates a positive effect on the heat content in the agglomeration bed, which leads to a shortening of the agglomeration time and possible fuel savings, see [1-4]. Based on experimental results, the partial use of lime in the agglomeration mixture also has a positive effect on the environment. Compared to limestone, quicklime improves the heat transfer in the agglomerated layer. With the same alkalinity and the same volume of fuel, the carbon dioxide / carbon monoxide ratio can change due to different amounts of carbonates after their replacement with lime. Even in the case of lime, the quality, granulometry, quantity and method of adding lime to the agglomeration process are very important for the characteristics and productivity of the agglomeration.

\section{PRODUCTION OF SINTERING BELT}

Assuming an unchanged charge composition and the same production technology, the amount of agglomerate produced is directly proportional to the speed of the sintering belt. In real conditions, the speed of the belt must be adapted to technological changes and the composition and sintering properties of the mixture. If the sintering belt speed is too high, sintering is not completed at the end of the belt. The movement of the sintering zone ends at a certain distance above the grate surface. The agglomeration mixture below this surface is not only dried and dried back into the batch as part of the return agglomerate. This fact significantly reduces the productivity of the sintering belt and destabilizes the further sintering process. When the speed of the sintering belt is too low, sintering ends well before the end of the suction area and the productivity rises sharply. The agglomeration mixture consists of small grains of ores, concentrates, alkaline additives and coke. The gaps between the individual grains can be considered as capillaries. According to this consideration, the capillary forces in the packaged mixture depend on the diameter and the number of gaps between the individual grains. The magnitude of the capillary forces is inversely proportional to the value of the mean grain diameter of the 
agglomeration charge. For this reason, the finest grains are best packaged and the finest concentrates are used for pelletization. The more water is added to the mixture, the more capillaries are filled with water and the better the packing conditions. Lime is a typical example of a substance that is commonly used to improve packability.

\section{SILO FOR DOSING LIME}

In addition, the lime storage shown in Figure 1 supports the packing process of the agglomeration mixture. To understand the flow of energy in the packing process, the specific energy given to the sintered layer by air, coke, drying and decomposition of lime is evaluated. The main source of energy is coke in the agglomeration mixture, in addition, a certain proportion comes from the hot gas during ignition. Part of the energy is used for decomposition limestone and dry the moisture in the mixture. in practice, very little energy is released into the chimney due to the combustion of gases, because the heat in the flue gas heating the mixed layer burns only the lower layers. Once the entire mixed layer is sintered, then the flue gas temperature is clearly rising. This burns the entire layer on the sintering belt.

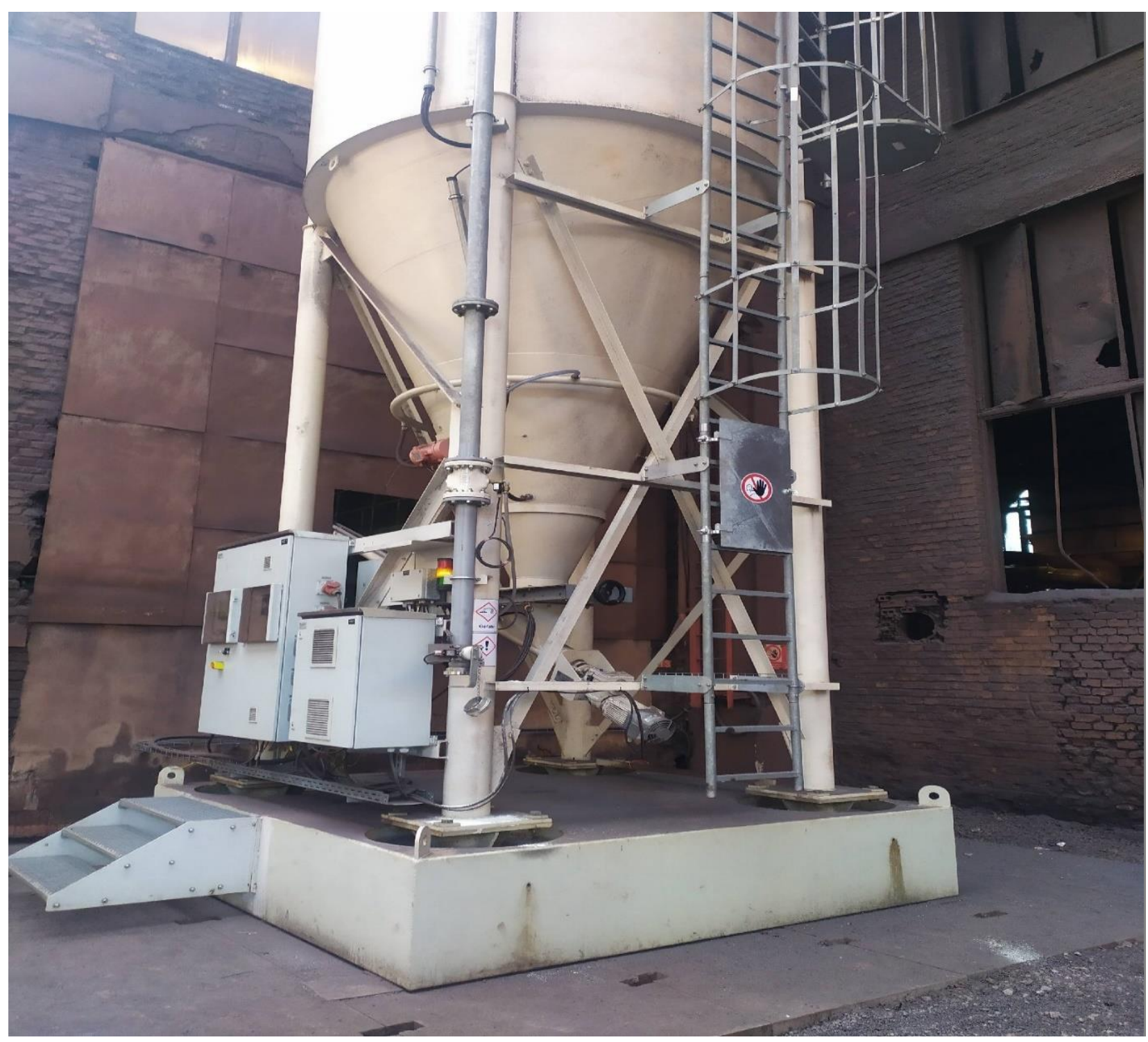

Figure 1 Lime storage 


\subsection{Function}

The silo is equipped with radar for continuous measurement of lime level. The regulation of the amount of lime is ensured by a frequency converter, which regulates only the screw conveyor No. 1, just below the silo hopper. The other augers are started by a contactor. In terms of starting the displacement to the first stage mixer. The gradual start sequence is from the last screw conveyor to the first screw conveyor. Each auger is started up to 5 seconds after the auger to which it is connected is started. Furthermore, the silo is equipped with a vibrator and a blower for pouring material from the walls of the tank. The silo can be operated in both local and remote control using visualization in the control room shown in Figure 2. It also possible to enter the required amount of lime for the visualization. There is also a counter for the amount of lime so far dosed.

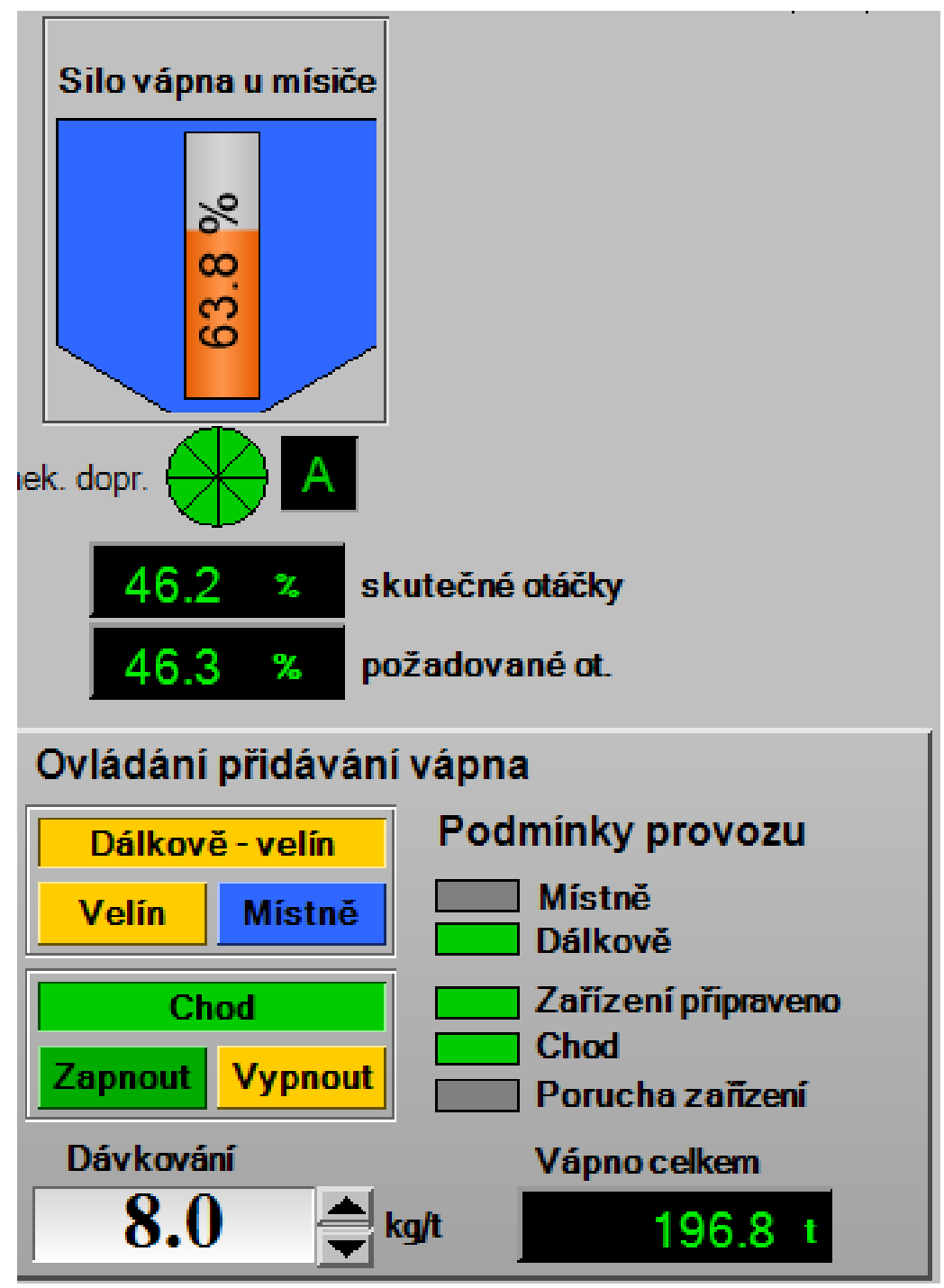

Figure 2 Promotic visualization

\subsection{Dosage control}

The dosage amount is calculated from two formulas, according to volume or weight. In the case of weight, the calculation is based on the dosing of lime into the mixer and the material of the agglomeration mixture fed to the mixer. In the case of volume, the calculation is based on the dosage of lime into the mixer and the bulk density of the lime. The frequency of the inverter for screw speed control No. 1 is based on the equation shown in Figure 3. A current loop of $0-20 \mathrm{~mA}$ is used as information for controlling the inverter and its feedback. 


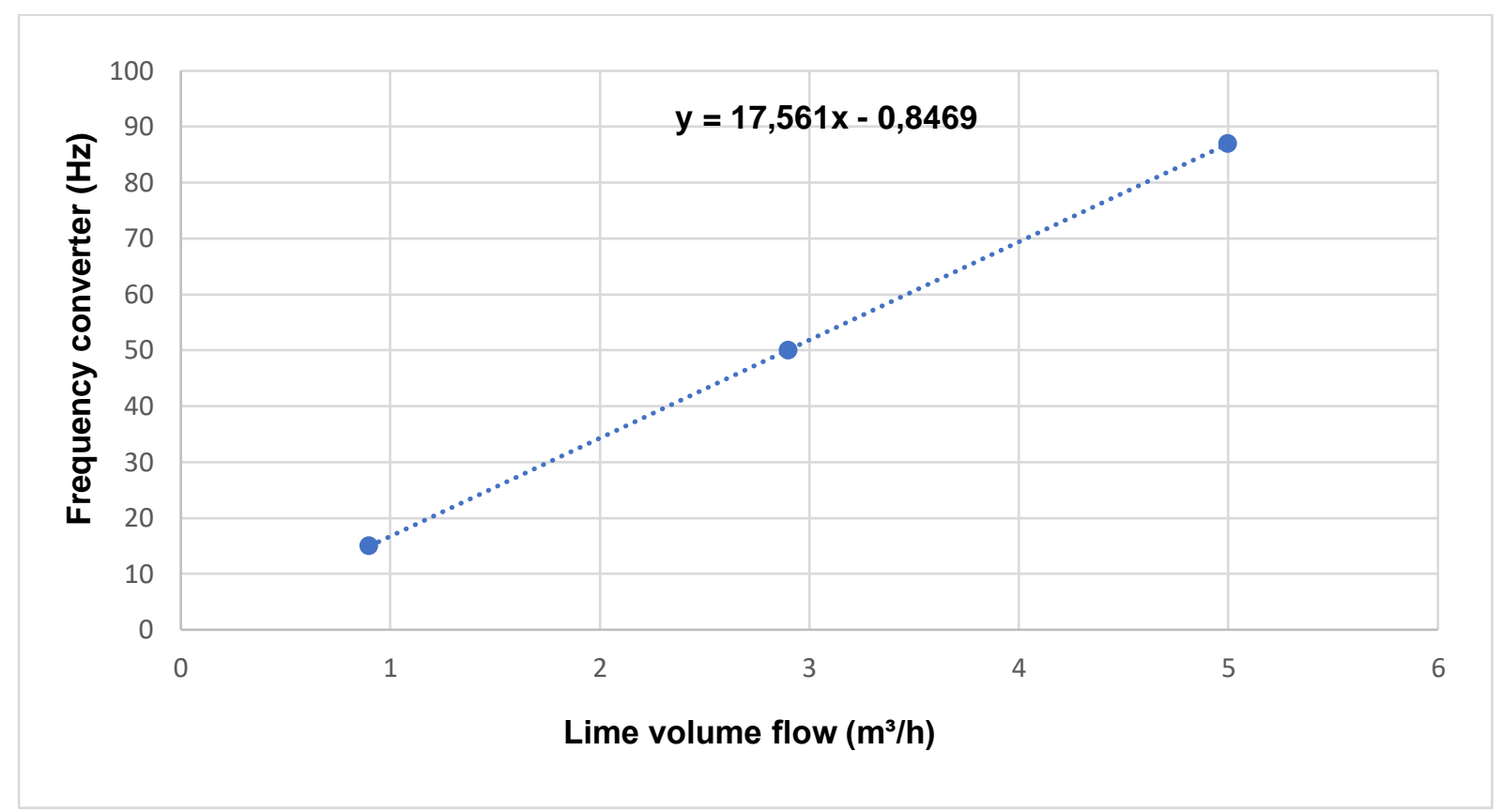

Figure 3 Graph of lime dosing, based on the frequency of the converter

\section{CONCLUSION}

From the data obtained, lime has a positive effect on the production of the agglomerate. Agglomerate production increased by an average of $10 \%$ due to packability. Another positive effect was recorded on the reduction of carbon dioxide and carbon monoxide emissions; there was a decrease of up to $20 \%$. The maximum disadvantages remain the maximum capacity of the production plant. In terms of productivity, the operation was on the verge of possibility. The lime control system was connected to the existing agglomeration control system (Siemens S400); the control was processed only with the help of unified signals. The silo system itself controlled the entire subsystem. The main control system, regulating the speed of the first auger based on the described algorithm. Similar tasks are solved in [5-8.]

\section{ACKNOWLEDGEMENTS}

\section{The work was created within the frame of projects No. SP 2021/23 and SP 2021/71}

\section{REFERENCES}

[1] BROŽ, Ludvík. Výpočtová cvičení z výroby surového železa. Ostrava: Vysoká škola báňská - Technická univerzita Ostrava, 1981.

[2] KRET, Ján. Základy a teorie technologie výroby železa a oceli. Ostrava: VŠB - Technická univerzita Ostrava, 2013.

[3] TŮMA, Jiří, DRABINA, Josef, HONZA, Otakar, STANĚK, Vladimír a MORAVEC, Pavel. Hodnocení redukovatelsnosti železorudných surovin pomoci matematického modelu. Hutnické listy. 1988, no. 4, pp. 228233.

[4] LAPČíK, Vladimír. Výrobní a environmentální technologie. Ostrava: VŠB - Technická univerzita Ostrava. 2008.

[5] JONSTA, P., VLCKOVA, I., KRISTAK, L., SPICKA, I., JONSTA, Z. Contribution to the thermal properties of selected steels. Metalurgija. 2015, vol. 54, no. 1, pp. 187-190. ISSN 0543-5846. 
[6] KOSTIAL, Pavel, SPICKA, Ivo, JANCIKOVA, Zora, VALICEK, Jan, HARNICAROVA, Marta a HLINKA, Josef. On Experimental Thermal Analysis of Solid Materials. Measurement Science Review [online]. 2014, vol. 14, no. 6, pp. 317-322. ISSN 1335-8871. Available from: https://doi.org/10/gfkbdr

[7] KOSTIAL, P., JANCIKOVA, Z., BAKOSOVA, D., VALICEK, J., HARNICAROVA, M. a SPICKA, I. Artificial Neural Networks Application in Modal Analysis of Tires. Measurement Science Review [online]. 2013, vol. 13, no. 5, pp. 273-278. ISSN 1335-8871. Available from: https://doi.org/10/gfkbds

[8] SPICKA, I., HEGER, M., ZIMNY, O., JANCIKOVA, Z. a TYKVA, T. Optimizing the model of heating the material in the reheating furnace in metallurgy. Metalurgija. 2016, vol. 55, no. 4, pp. 719-722. ISSN 0543-5846. 